\title{
COUNCILS, COMMITMENT, OPPORTUNITY AND RELATIONSHIPS: HOW THEY COMBINE TO PROMOTE PHYSICAL ACTIVITY
}

Margaret Thomas, Shauna Corne,

Jenni Humphries, Jeni Bindon

Central Sydney Health Promotion Unit

T his article describes a project to provide information to support members of a local community in increasing their level of physical activity. It provides an example of the need to work intersectorally to achieve health promotion goals ${ }^{1}$, a need which is particularly strong in the promotion of physical activity, where some aspects of the development of supportive environments are outside the scope of the health sector ${ }^{2}$.

In 1995 the Central Sydney Area Health Service Health Promotion Unit invited local interested parties (including representatives of local government, the local Division of General Practice, the National Heart Foundation and the local office of the Department of Sport and Recreation) to inaugurate a physical activity intersectoral working party. The Health Promotion Unit followed up the initial meeting by visiting each member of the working party to establish whether the most appropriate representative had attended the meeting and to investigate the core business of the group or organisation. At this stage we indicated our willingness to work on physical activity projects undertaken by the representatives' own organisations.

The members' enthusiasm and commitment to the working party has been maintained by establishing good informal relationships, and by working individually with members of the group to assist them with their own projects.

\section{THE DRUMMOYNE WALKING MAPS PROJECT}

One of the substantial projects undertaken by the working party was to develop maps promoting walking paths in the Drummoyne area. This project was carried out in partnership with Drummoyne Council. It was our good relationship with the council that enabled us to initiate this project, and our collaboration with the council's community services worker helped to foster the relationship.

The partnership with Drummoyne Council was strengthened by the fact that the maps would appear to the public as a council product.

Once we had established good working relationships, the success of the project rested on the commitment of the council to undertake its share of the work. A council worker mapped the distance of each walk, contributed to the design of the maps and drafted briefing notes for the mayor for the public launch. She also engaged her manager in the process so he was supportive of the project. His organisational position helped with crucial decisions, such as the council's decision to provide funding.

A local shopping centre sponsored the printing of the maps, provided a venue for the launch of the maps and helped to secure some local media coverage, in return for the use of its logo.

Working with Drummoyne Council on the walking maps project acted as a stimulus to promote local facilities and also helped to heighten the council's awareness of the importance of environments in the promotion of physical activity. Following the success of this project, we are working with a number of councils on a range of physical activity projects.

\section{CONCLUSIONS}

In our experience, the three key factors for successful intersectoral action are:

\begin{tabular}{l|l} 
- & $\begin{array}{l}\text { relationships } \\
\text { commitment } \\
\text { opportunity }\end{array}$
\end{tabular}

Working intersectorally has resulted in strong organisational relationships which will greatly enhance the promotion of physical activity in Central Sydney.

1. Harris E, Wise M, Hawe $P$, Finlay $P$, Nutbeam D. Working together: intersectoral action for health. Canberra: AGPS, 1995.

2. Bauman A, Bellew B, Booth M, Hahn A, Stoker L, Thomas M Towards best practice for the promotion of physical activity in the Areas of NSW. NSW Health Department, Centre for Disease Prevention and Health Promotion, 1996.

\section{A local media campaign}

- Continued from page 22

The local Illawarra television station also seeks opportunities for involvement in local community-based activities, as well as being interested in paid advertising.

\section{CONCLUSION}

It can be an advantage to operate at a local level in attempting to form collaborative relationships with the commercial sector. Many regional commercial organisations position themselves as local businesses, and for this reason seek associations with projects that are clearly communitybased. Associations with important, positive, "feel-good", preventive health campaigns reflect positively on the sponsoring organisation at the local level.

However, this in itself is not generally enough for businesses in competitive market environments. The fact that we had some money to put towards the campaign was extremely important, because it indicated the level and intent of our commitment. Since the Illawarra Physical Activity Project became a paying advertiser, the television station has been extremely helpful in covering other project stories, and is receptive to press releases from our project office. The value-added nature of the relationship was extremely important in ensuring it could be sustained.

Another advantage of working at a regional level is that it makes possible the development of personal relationships with commercial sector decision-makers. This is extremely important in helping to mesh health and commercial sector objectives, and allows far greater involvement by the commercial sector. Although the commercial media may not choose to be highly involved in a practical way, such a relationship greatly enhances the sense of being partners in a positive process.

1. Redman S, Spencer E, Sanson-Fisher R. The role of mass media in changing health-related behaviour: a critical appraisal of two models. Health Promotion International 1990; 5:85-100.

2. Owen N, Bauman A, Booth M, Oldenburg B, Magnus P. Serial mass media campaigns to promote physical activity: reinforcing or redundant? American Journal of Public Health 1995; 85:244-248. 